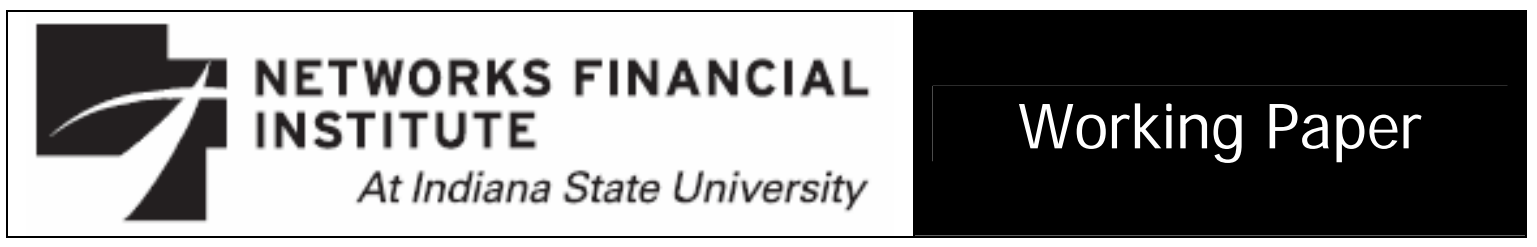

2007-WP-15

April 2007

\title{
Turnover and Return in Global Stock Markets: A Time Series and Cross Sectional Analysis
}

\author{
Malay K. Dey
}

Abstract: I study the liquidity of global stock exchanges and how it determines cross sectional returns on stock portfolios of the exchanges. I measure liquidity by turnover ratio computed as value of shares traded over the market capitalization. I obtain data from FIBV, an association of global stock exchanges and conduct a univariate analysis of turnover ratio. I find evidence that liquidity is trend weakly stationary for most stock exchanges, however, exchange and time specific factors are more appropriate for modeling liquidity. In a multivariate regression model, I find age, size, type of exchange, competition for order flow, and growth rate to be significant determinants of liquidity. The exchange specific factors are surrogates for the legal systems, English common law, and Civil laws of the countries. I estimate the parameters of a multiple regression model in a two stage GLS framework in which index return is a function of turnover. The significant determinants of index return are size, turnover, and volatility, although some of the volatility effect may be a spillover from a January effect. Investors expect higher return from high turnover markets. The turnover return relation is found to be true only in emerging markets and not in developed markets. This result confirms existing empirical evidence that high turnover stock portfolios generate superior returns.

About the Author: Malay K. Dey is currently an Assistant Professor of Finance at Morgan State University in Baltimore, Maryland. He graduated with a Ph.D. in finance from the University of Massachusetts Amherst. His primary research interests are market microstructure, international financial markets, and financial econometrics. Professor Dey has published in Emerging Markets Review and has several working papers currently under review at major economics and finance journals.

Keywords: Stock exchange, Legal systems, Return, Liquidity, Turnover ratio

* This work is supported by Networks Financial Institute. I thank Mohamed Warsame for his research assistance, and Alex Tang for his helpful comments. I also gratefully acknowledge comments received at Southern Finance Association Meetings, 2002, Global Finance Association Annual Meetings, 2004, and the Finance Seminar at the University of Delaware.

The views expressed are those of the individual author and do not necessarily reflect official positions of Networks Financial Institute. Please address questions regarding content to Malay Dey at mdey77@yahoo.com. Any errors or omissions are the responsibility of the author.

$\mathrm{NFI}$ working papers and other publications are available on NFI's website (www.networksfinancialinstitute.org). Click "Research" and then "Publications/Papers." 


\section{Introduction}

Turnover ratio (also called turnover), value of shares traded during a period, as a percentage of market value of shares outstanding is a measure of liquidity. Recently

Datar, Naik, and Radcliffe (1998) (later DNR), and Easley, Hvidkjaer, and O'Hara (2002) (later EHO) use turnover ratio to test the empirical implication of Amihud and Mendelson (1986) (later A\&M) and report convincing evidence that for individual securities, return and turnover are inversely related and that investors demand a premium for holding illiquid stocks. Kane (1994) extends the results of A\&M to quoted and non-quoted liquid assets like non-traded portfolios. Recently, turnover ratios for stock portfolios are computed and analyzed as well. Boutchkova and Megginson (2000) investigate the role of privatization as a determinant of stock market turnover; Rouwenhorst (1999) report an increasing relation between portfolio turnover and return in emerging markets; and Wermers (2000) conclude that high turnover mutual fund portfolios generate excess return over a passive, Vanguard index fund. The positive relation between portfolio turnover and return documented by Rouwenhorst (1999) and Wermers (2000) suggests that an active management of an index and its composition may lead to higher turnover and growth in its value. Domnowitz, Glen, and Madhavan (2001) argue that consideration of transactions costs and turnover may lead to a change in the composition of global efficient portfolios.

In this paper, I investigate the relation between the return on a stock exchange index and the corresponding turnover computed as value of shares traded over market capitalization for the stock exchange portfolio. It is perhaps worth noting here that 
turnover for an individual security represents approximately the fraction of outstanding shares traded during a period; however, as shown in Appendix A, portfolio turnover computed as value of shares traded over market capitalization for a portfolio turns out to be an equally weighted average of value of shares traded for individual securities in the portfolio, the weight being one over the market value of the portfolio. Thus portfolio turnover denotes both the composition (reciprocal of market capitalization) and the liquidity (value of shares traded) of the portfolio and it is not clear how those components affect the turnover-return relation as documented in Wermers (2000) and Rouwenhorst (1999).

Specifically, I address the following questions. What are the primary determinants of turnover for a stock exchange? Is there a systemic difference in turnover between exchanges classified by some common attributes e.g., order vs. quote driven trading systems, single vs. multiple locations or their interactions? Further how does turnover affect return for exchange portfolios and is the return turnover relation different between exchanges in emerging and developed markets?

I obtain data on stock exchange portfolios from FIBV, Federation of International Stock Exchanges to conduct an econometric analysis of the relation between portfolio return and turnover ratio in two parts. First I propose and test a regression model for determining turnover from exchange specific factors, e.g., quote or order driven market, single or multiple markets denoting competition for order flow, that may be classified as market microstructure factors along with size, age of the exchange, and growth. Results from several regression models suggest microstructure factors are in certain cases important determinants of turnover, as are size, age of the exchange, and growth. I find 
evidence that a regime switching, exchange specific fixed effect model most appropriately captures the microstructure components in determining turnover. The Fstats for model fit for several regime switching, one way fixed effect models exceed those of all other pooled OLS and two way fixed effect models by a considerable margin. I investigate and find that the exchange specific effects are explained by differences in legal systems, English common law vs. Civil laws (French, German, Scandinavian and others) but not by differences between emerging developed markets. Exchanges in English common law countries provide more uniform shareholder protection across all market types, and thus enjoy increased liquidity compared to their counterparts in Civil law countries.

Second, I hypothesize that turnover is a determinant of return on equity markets after controlling for size, and volatility, and estimate the parameters of the model from a two-stage GLS method. Econometrically, the two-stage GLS method is necessary since a univariate analysis of turnover ratio suggests a non-deterministic trend component in turnover ratio in a large number of exchanges. The non-stationary component persists even after detrending and deseasonalizing the data, which opens the possibility that OLS estimates of regression coefficients will be biased and spurious. The estimated regression equations based on GLS method consistently demonstrate a direct positive relation between turnover and portfolio return across several models. The GLS estimates also prove to be much improved in terms of reduced bias and improved efficiency. Further analysis on a sample excluding the month of January indicates that a January effect exists - the GLS estimates of coefficients for turnover are reduced to almost half of that in the full sample, and for volatility the coefficients become significantly negative thus 
predicting an inverse relation between volatility and return. I also find evidence that in my sample, the significant and increasing relation between turnover and return is true exclusively for the emerging markets, and that developed markets show a significant relation between return and volatility but not between turnover and return.

This study contributes to three strands of literature on return and liquidity of global stock markets. First, it complements recent studies by Clayton et al (2000), Minier (2000), and Boutchkova and Megginson (2000) in which the authors have primarily sought to relate economic fundamentals to the formation, and liquidity of stock markets respectively. Second, it ties the microstructure elements of financial markets to the broader legal system as determinants of financial market performance and thus complements the fledgling literature pioneered by La Porta et al $(1997,1998,2002)$ (LLSV later) and expanded recently by Eleswarapu and Venkatraman (2002) (later EV) among others; and third, it provides new evidence in support of Rouwenhorst (1999) and Wermers (2000) regarding the relation between return and turnover of stock portfolios particularly highlighting the difference between emerging and developed markets.

\section{A. Liquidity, Turnover, and Return in Global Stock Markets}

The last decade of the millennium witnessed proliferation of securities exchanges, particularly stock exchanges in the world. At the beginning of the decade in 1990 there were 160 stock exchanges in the world. By the end of 2000, there are more than $215^{1}$

\footnotetext{
${ }^{1}$ Coffee (2002) counts 150 currently operational stock exchanges.
} 
stock exchanges, an increase of over 30 per cent. The fact that the history of stock exchanges dates back into the $16^{\text {th }}$ century ${ }^{2}$, this growth in just one decade is impressive. This proliferation is due simultaneously to the increased demand for publicly traded stocks as a vehicle of investment, and increased supply of securities by new and old firms that continue relying less on bank financing and more on capital markets for financing their projects as documented by Beck et al (2000). A major part of this increase is also due to the share issue privatization (SIP) programs of several formerly Warsaw Pact Eastern European nations (Boutchkova and Megginson [2000]).

The organization and structure of these exchanges are as varied as their trading rules are ${ }^{3}$. While most of the new ones are multiple dealers, quote driven trading systems, among the old ones there exist a significant number of order-driven, traditional floor exchanges. Although the emerging economies saw the largest increase in both new investments and market developments, the developed economies did get a share of these enhancements mostly through restructuring ${ }^{4}$ of the financial marketplace.

It is not clear how trading system designs affect the efficiency and liquidity of stock markets. However, since in financial markets every transaction is a bundle of two goods and services that are simultaneously bought and sold - a financial contract and liquidity services, the return depends on both the expected realizable value of the contract, and the timeliness of the payoff or liquidity. The dealers and market makers provide timely liquidity and charge a price for their services. Thus one would expect to

\footnotetext{
${ }^{2}$ Among existing stock exchanges in the world, the earliest on record is Hanseatic Stock Exchange in Hamburg (later Hamburg Stock Exchange) in Germany opened in 1558.

${ }^{3}$ Harris (2003) contains an excellent discussion of the rules and structures of securities trading.

${ }^{4}$ Most of these restructuring are in the form of consolidation of and merger between rival stock exchanges (e.g. CNDX in Canada) and brokerage firms (e.g. US), improvements in the networking facility, and expanding to off-floor trading activities, namely third and fourth markets (e.g., Instinet).
} 
find a relation between return and liquidity however measured for individual and portfolios of securities.

In spite of its importance "there is no single, unambiguous, theoretically correct measure of liquidity" (Duvofsky and Groth [1992]). Baker (1996) suggests the following alternative measures of liquidity: bid ask spread, volume based liquidity ratio, market adjusted liquidity, Marsh-Rock liquidity ratio, and variance ratios. Among the different measures of liquidity, two volume based measures, value of shares traded, and turnover ratio computed as value of shares traded over market capitalization (note that turnover ratio actually denotes the percentage of outstanding shares traded during a period) are the most primitive, albeit the most easily accessible measures ${ }^{5}$. Nevertheless, the literature on the econometric analysis of turnover ratio is very limited.

In terms of liquidity, EV (2002) follows up on LLSV and report significant differences in cost of liquidity due to variations in political risks and institutional arrangements. In the context of portfolios, Boutchkova and Megginson (2000) report a positive impact of privatization on turnover ratios of stock exchanges, and Frost, Gordon, and Hayes (2002) (later FGH) report increased liquidity for stock exchanges with stronger disclosure and monitoring rules. Regarding the relation between turnover and return for individual securities, DNR (1998), and EHO (2002) present evidence consistent with A\&M (1986) hypothesis that in equilibrium, traders will demand higher return for illiquid stocks and thus there is an inverse relation between liquidity and return. For portfolios, FGH do not find any relation between turnover and realized return, while Rouwenhorst (1999) reports a positive relation between turnover and return for emerging

\footnotetext{
${ }^{5}$ DNR (1998) point out that dollar trading volume lacks standardization and hence an inappropriate measure of liquidity for an individual security and uses turnover ratio instead.
} 
market portfolios, and Wermers (2000) report that actively managed, high turnover mutual fund portfolios consistently earn excess return over passive, low turnover index funds. The positive relation is contrary to the well-documented negative relation between turnover and expected return for individual securities and its connotation is still a subject of investigation. Nevertheless, one plausible hypothesis is that portfolio turnover is a weighted average and the weight may denote the composition of the portfolio, which affects return on the portfolio.

\section{B. Multiple Regression Analysis of Turnover Ratio}

B.1. Data and descriptive statistics

I obtain monthly data on value of shares traded, market capitalization, number of firms listed, and market value of a corresponding index on 48 FIBV member exchanges for the period 1995 through 2001. As of the end of 2001, the FIBV ${ }^{6}$ (Federation of International Stock Exchanges) database contains trading and capitalization data on its 55 member-exchanges spanning all the continents. For the purpose of this paper, I excluded exchanges on which data are available only since 1998 or later e.g., CDNX (that was formed as a merger between Vancouver, Alberta, and Montreal), Bermuda, Ljubljana, Malta, Valencia, and Colombo and exchanges that are not primarily stock exchanges e.g., Chicago Mercantile Exchange. Most of the sampled 48 stock exchanges have data for the complete sample period (1995-2001); a few do not do not for a variety of reasons ${ }^{7}$.

\footnotetext{
${ }^{6}$ All data from FIBV used in this study are publicly available from FIBV website www.fibv.org.

${ }^{7}$ The most common reasons are that the exchange did not exist / submit operational data since the beginning of the sample period in 1995 and/or ceased to exist before the end of the sample period in 2001 .
} 
The span of the available data for each exchange is listed in Table 1. In all, I obtain a panel of 3826 observations from 48 stock exchanges over a period of $60-84$ months. I obtain data on institutional features, trading rules, and some of the country specific information manually from the websites of FIBV and also the individual stock exchanges.

Table 1 reports the means and standard deviations of monthly market capitalization and dollar trading volume (value of share trading) for the stock exchanges. The largest five markets in terms of market capitalization are NYSE, Tokyo, Osaka, NASDAQ, and London, while the smallest five markets are New Zealand, Tehran, Warsaw, Lima, and Vancouver. Among the five large markets, NYSE has overwhelming dominance in terms of market capital, since it is bigger than any three of the remaining four combined. The same five also are the most volatile markets in the world measured by the standard deviation of market capital. In terms of liquidity measured as dollar trading volume, the two US markets, NASDAQ $(\$ 677,388 \mathrm{~m})$ and NYSE $(\$ 604,000 \mathrm{~m})$ top the list followed by London $(\$ 237,000 \mathrm{~m})$, Tokyo and Germany (both around $\$ 108,000 \mathrm{~m})$. Once again the dominance of US markets is evident. Among the five low capitalization (small) markets mentioned earlier, three (Lima, Tehran, Vancouver) also appear in the smallest five in terms of dollar trading volume. In fact, these three markets (Lima, Tehran, and Vancouver) from three different continents share a lot of common features namely low market capitalization, thinly traded and low volatility markets. Although the smallest and relatively less volatile markets are scattered in all the continents, it is apparent that in terms of average market capitalization and volatility, there is a regional pecking order with N. America at the top, followed by Asia/Pacific, 
Europe, and finally S. America; however in terms of liquidity measured as trading volume in dollar, and its volatility the pecking order is N. America, Europe, Asia/Pacific and S. America. Thus while N. America (S. America) is the largest (smallest), and most (least) volatile market in terms of both market capitalization and dollar trading volume and their respective standard deviations, Europe and Asia/Pacific alternate their ranks both for size (market capitalization and dollar trading volume) and volatility (standard deviations of market capitalization and dollar trading volume) in the hierarchy. Thus the price of growth and liquidity in terms of risk is evident in the global markets.

I compute monthly turnover ratio as value of shares trading in any month over market capitalization at the beginning of that month. Table 2 reports the descriptive statistics - mean, median, standard deviation, high and low points of turnover ratio. The high turnover (means between .364 and .132) exchanges are Amex ${ }^{8}$, NASDAQ, Taiwan, Korea, and Istanbul, while the low turnover (means between .003 and .009) exchanges are Luxembourg, Montreal, Barcelona, Osaka, and Rio de Janeiro. Note that the highest (lowest) turnover exchanges are neither the highest (lowest) market capitalization exchanges, nor the most (least) liquid (dollar trading volume) exchanges. Nevertheless, the regional distribution of turnover ratio in terms of all three statistics, mean, standard deviation, and range (maximum-minimum) shows North America leading followed by Asia/Pacific, Europe, and finally South America. This ranking of the regions resembles that of the mean and standard deviation of market capitalization and not of dollar trading volume, which confirms that turnover ratios of portfolios have more in common with market capitalization than dollar trading volume.

\footnotetext{
${ }^{8}$ Amex's high turnover 1.364 is for March 2000. Although it is an outlier, Amex mean turnover without it is still quite high, 0.352 .
} 


\section{B.2. Regression model and results}

I propose the following regression model for portfolio turnover.

1. Turnover $_{i t}=\alpha_{L}+\beta_{1}$ Trend $_{i t}+\beta_{2} \ln \left(\right.$ Size $_{i t}+\beta_{3}$ Xtypedum $_{i}+\beta_{4}$ Age $_{i}+\beta_{5}$ Mmktdum $_{i}+\varepsilon_{\text {Lit }}$.

Essentially the model suggests a linear relation between turnover and size after adjusting for a deterministic time trend for an individual exchange, if any. I measure size as market value of equities, and alternatively as number of firms. Further I hypothesize that the age, the organization structure, and the competition for order flow from other exchanges in the same country would also affect the turnover of exchanges. These three variables are time invariant - age for an exchange is defined as (2000-the year of opening) ${ }^{9}$, the organization structure is a dummy variable (type dummy) that obtains a value 0 if the exchange is order driven, and 1 if the exchange is quote driven, and competition for order flow is a dummy variable (multi market dummy) that obtains a value 0 if the exchange is the only stock exchange in the country, 1 otherwise.

I estimate the parameters of the regression equation by a pooled OLS method and report the results in Table 3A. Model 1 indicates a significant linear relation between turnover (liquidity) and size. Everything else remaining constant, larger markets on average are more liquid than smaller markets. Further, the significant coefficients for log (age), exchange type dummy, and multi market dummy indicate that other things remaining constant, relatively younger exchanges are more liquid than their older counterparts, order driven markets enjoy higher liquidity than that of quote driven markets, and exchanges with competition for order flow in their home country are more

\footnotetext{
${ }^{9}$ I could have let age vary with time. That would have in effect introduced a time trend in the age variable, and made it collinear with the trend variable. My interest is in determining how the cross sectional variability in age explains the variation in turnover.
} 
liquid than exchanges without competition. Overall the findings are quite interesting. While as expected larger markets enjoy higher liquidity, but new exchanges seem to be outpacing the more established exchanges in terms of liquidity. This inverse relation between liquidity and age of an exchange is consistent for all the models for liquidity. On the contrary, the relatively few order driven markets enjoy higher liquidity than the vast majority of quote driven markets and further one-country-one-exchange does poorly in respect of liquidity as compared to multiple exchanges promoting order flow.

Model 2 replaces $\log$ (market value) with $\log$ (number of firms) to proxy for size effect. $\log$ (number of firms) seems to capture the intuitive size effect that everything else remaining constant, exchanges with more listings have higher liquidity; but even goes beyond it to capture the information content in exchange type and multi-market dummies thus rendering those dummy variables insignificant. This indicates that exchanges with high (low) number of firms are also multi market (single exchange) and quote (order) driven. La Porta $(1997,2002)$ find countries with better shareholder protection have higher firm values, higher stock market capitalization, and larger number of listed firms per capita. Thus both size, and number of firms but perhaps the later more than the former denotes a common law based corporate governance system in which shareholders rights are better protected (La Porta [1997]). I investigate this question later through some tests of associations.

Model 3 introduces a growth variable in lieu of the size effect. Growth is computed as $\left[\left(\right.\right.$ market value $_{t} /$ market value $\left.\left._{t-1}\right)-1\right]$ and measures the rate of growth of the equity portfolio in each exchange. Although an exchange specific variable, this variable thus measured can proxy for several economy wide factors. For example, to the extent 
that growth in stock market is correlated with the current growth and/or signals future growth in the economy it may represent a potential macro level growth rate. This may even indicate a level of liberalization and openness in the economy since market value will increase over time due to more listings, more secondary issues, all of which are induced by greater liberalization and relaxation of capital market constraints, and improved shareholder protection offered by common law countries (La Porta [1998]).

Model 3 with the growth variable is significant at greater that $99 \%$ level of confidence. The signs and magnitudes of the coefficients are comparable to those in Model 1 and thus it appears that the growth variable contains similar information as size. This is intuitive since exchanges with high growth rate appreciate faster and end up being large markets; however, it is not clear how the converse ${ }^{10}$ is true. In order to further investigate if growth captures the size effect, or it has explanatory power beyond size effect, I run models 4 and 5 adding a growth variable to Models 1 and 2 respectively. The nature of the results remain the same as in models 1 and 2 - the growth variable itself is significant (the coefficients are positive indicating higher growth attracts more liquidity) at higher than $99 \%$ degree of confidence, and adds substantial information to the models in terms of increasing adjusted $\mathrm{R}^{2}$, from $6 \%$ in Model 1 to $7 \%$ in model 4 $(+16 \%)$, and $8 \%$ in model 2 to $9 \%$ in model $5(13 \%)$ respectively. All the models (Model 1-5) include number of observations to adjust for a deterministic trend component and all the models exhibit a significantly positive time trend, implying on average there is a

\footnotetext{
${ }^{10}$ It is not clear why larger markets have higher growth since large corporations tend to become stagnant and growth averse. Nevertheless, one hypothesis is that larger markets respond to changes faster and more effectively than smaller exchanges, have more resources available to undergo changes, or it may be that growth momentum spills over several periods into the future.
} 
positive growth in turnover over time. Although the coefficients change, the results are qualitatively similar without the time trend.

Two important observations from Table $3 \mathrm{~A}$ are that the two dummy variables, exchange type and multi market dummies are not independent, and number of firms capture the covariance between those two variables. One possible explanation for both these observations is due to a three-way association between legal systems, exchange type, and multi market dummies. In order to test any association between legal systems, exchange type, and multi market dummies, I identify the legal system associated with each stock exchange from FGH and classify those as English common law vs. Civil law (French. German, and Scandinavian). On the basis of test of association (CochraneMantel-Haenszel test), I cannot reject the hypothesis that there is no association between legal systems and exchange type (order vs. quote), and legal systems and market type (single vs. multi market). However, Cochrane-Mantel Chi-square (3.021) test of association for exchange type and market type is significant at greater than $95 \%$ level of confidence. Additional tests show that this association between exchange type and competition for order flow (single vs. multiple markets) is significant only for Civil law countries and not for English common law countries, which implies that securities markets laws are more uniform under English common law than those under the Civil laws systems. Under English common law, the competition for order flow is independent of the type of market, whether order or quote driven; under Civil laws, market type guarantees competition for order flow.

In order to better understand the relation between size and turnover (liquidity), particularly the effects of the interactions among the dummy variables noted above e.g., a 
quote driven market with or without competition for order flow or some other omitted variables on the slope coefficient, I run a panel regression model with two way fixed effects as below. The cross sectional effects indicate exchange specific differences, while the time effects indicate if differences in liquidity arise due to changing times. A time trend is not necessary since there is already a time effect in the model.

$$
\text { 2. Turnover } r_{m n}=\alpha_{L}+\beta_{1} \ln (\text { Size })+\sum_{m=1}^{47} \lambda_{m} \mu_{m}+\sum_{n=1}^{71} \gamma_{n} \eta_{n}+\varepsilon_{L m n} \text {. }
$$

I report the results of this regression model in Table 3B. First, note that the null of notwo way fixed effect is rejected for all four models at greater than $99 \%$ level of confidence and the $\mathrm{R}^{2}$ counts to greater than 60 percent. Contrary to the results from the pooled OLS model, growth although is significant at greater than $99 \%$ level of confidence, adds very little to the overall $\mathrm{R}^{2}$ for the models, which implies that the cross sectional and time effects explain more of the variation in turnover than growth does.

On further analysis of the results, I find that there are three distinct regimes during the sample period, January 1996-June 1997, July 1997-May 2000, and June 2000December 2001 in terms of turnover volatility. During 1996-97, every time period had an impact on turnover; during 1997-2000 movements in turnover were random and some periods had effects, while others did not; finally, during 2000-01, it was an absolute tranquil period where no single period had any significant impact on variation in turnover. Two inferences can be made from these findings. First, it raises a question regarding the stability of the regression parameters over multiple periods; an issue that will be addressed in the next section where turnover is used as a regressor variable. 
Second, it justifies fitting a one-way fixed (cross sectional) effect model for each of the three time periods (regimes) as an appropriate and parsimonious model for turnover. In order to fit a regime switching regression model, I define a regime dummy variable as follows:

If time is between 1996-1997, regime dummy $=-1$;

If time is between 1997-2000, regime dummy $=0$;

If time is between 2000-2001, regime dummy $=1$.

The model estimates are reported in Table 3C. First, regime dummy is significant in all the models (1-4) with a positive coefficient ranging from 1.5 to 1.7 . Thus relative to the base period 1997-2000 (regime dummy = 0) intercept, the intercept is higher for the period 2000-2001 and lower for the period 1996-97. Size denoted by market value is not a significant determinant of turnover, but number of firms and growth are. That number of firms remains a significant determinant of turnover but market capitalization does not, supports La Porta (1997) who argues number of listing to be a more robust indicator of liberalization and common law protection of shareholders' rights than market value. The F-stats of 100.43, 94.06, 103.43, and 96.52 for Models 1-4 respectively denoting the model fit exceed that of similar pooled, and two-way panel models by a very large margin implying a superior fit for the one way regime switching models.

Regarding cross sectional effects in the one-way effect models, we find that 21 cross sectional effects are significant (14 positive, 7 negative) at greater than $90 \%$ level of confidence; the remaining 27 cross sectional effects are not significant. The cross sectional effects are spread into all continents, with 3 in N. America, 3 in S. America, 11 in Europe-Africa, and 4 in Asia-Pacific. The significant positive effects are spread into 
English (4) and civil (11) legal systems, while all six negative coefficients are from civil laws countries. The Cochrane-Mantel-Haenzsel test of association (5.049) between legal system and number of positive, negative, or not significant fixed effects is significant at greater than $95 \%$ level of confidence. Thus there is variation in Civil law countries in terms of high or low turnover, but English common law countries consistently provide positive intercepts i.e., higher turnover than the mean of the rest. These findings are consistent with those in LLSV $(1997,1998,2002)$ and EV (2002).

\section{Cross Sectional Return: Regression Model and Results}

I intend to use a dynamic regression model to capture the information content in our panel (time series-cross sectional) data. Consider the following regression equation.

$$
\text { 3. }{\text { Re } \text { urn }_{i t}}=\alpha_{R}+\beta_{1} \text { Turnover }_{i t}+\sum_{j=1}^{J} \beta_{j} X_{i t}+\varepsilon_{\text {Rit }} \text {. }
$$

Also recall equation 1 from above.

$$
\text { Turnover }_{i t}=\alpha_{L}+\beta_{1} \text { Trend }+\beta_{2} \ln \left(\text { Size }_{i t}+\beta_{3} \text { Xtypedum }_{i}+\beta_{4} \text { Age }_{i}+\beta_{5} \text { Mmktdum }_{i}+\varepsilon_{\text {Lit }}\right. \text {. }
$$

Note that turnover ratio is the dependent variable in equation 1, and a regressor variable in equation 3 . Thus equation 3 can be written in terms of equation 1 and being a recursive equation, OLS estimates are unbiased and efficient. However that requires making certain assumptions about the time series properties, particularly the stationarity conditions for turnover as a function of the error terms such that the regression does not end up being a spurious regression, and the estimates thereof biased. I check for stationarity conditions for turnover ratio in the following section. 


\section{C.1. Univariate Analysis of Turnover Ratio}

The two principal components of the univariate analysis of turnover ratio are trend and seasonality. By plotting the graphs (not included) of turnover ratios, I locate a mild trend, mostly increasing but sometimes decreasing, in turnover ratio over the sample period for most exchanges. Further with monthly data and evidence of month end effects in financial time series, I suspect seasonality too. The trend and seasonality cause nonstationarity in turnover ratio, which leads to spurious regression, if the non-stationary data is used in a regression framework.

I fit a deterministic trend line and report the trend component along with the corresponding t-statistics in Table 4. Out of 48 exchanges, 25 exchanges have witnessed a significant (null hypothesis: trend coefficient 0 ) upward trend in turnover. For 10 exchanges, including Osaka, Mexico, and Rio de Janeiro the null hypothesis of no trend in turnover cannot be rejected, while for 13 exchanges namely, Buenos Aires, Irish, Kuala Lumpur, Lima, Lisbon, Montreal, Philippine, Santiago, Sao Paulo, Swiss, Vancouver, Vienna, and Warsaw there is evidence of a significant downward trend. Thus there is no evidence of a common, systemic trend in turnover (liquidity) for all exchanges; rather there is evidence of exchange specific effects on turnover.

I use residuals from a trend regression and apply Augmented Dickey-Fuller test on the residuals to identify and remove the trend and seasonality respectively in the data. To determine the appropriate level of seasonal differencing that is necessary, the following model ${ }^{11}$, with and without the intercept, is estimated for the individual stock exchanges.

\footnotetext{
11 The model is for detrended residuals and thus the model for turnover is Turnover $=\alpha+\beta t+\gamma L_{t}^{-12}+\varepsilon_{t}$.
} 


$$
\text { Turnover residual } l_{t}=\omega+\gamma L^{-12}+\varepsilon_{t}
$$

Where $\varepsilon_{t} \sim N(0,1)$.

I report results from the ADF test for seasonality for each exchange in Table 3, along with a white noise test for the residuals. As evidenced by the ADF test, the detrended residuals appear to be stationary for most exchanges (exceptions are Amex, Rio de Janeiro, and Stockholm) and mostly do not require any seasonality adjustment. However, tests of white noise for the residuals are rejected for all of the exchanges except Lima, London, Mexico, Osaka, Rio de Janeiro, Thailand, and Warsaw. Thus turnover ratios for the global stock exchanges do not appear to be all trend stationary; although a deterministic trend appears to have a good fit for a few exchanges. It might be that a stochastic rather than a deterministic trend is an appropriate modeling tool for turnover ratio. It is also quite clear that some exchange and time specific factors affect the turnover of the stock exchanges over time. Instead of further exploring the nature of the non-stationarity, in the next section, I construct a regression model for turnover with time variant and time invariant exchange specific determinants.

\section{C.2. GLS method}

The preceding univariate analysis of turnover ratio and the panel regression model with fixed effects, that turnover residuals are not stationary for all exchanges, OLS estimates may be biased and inefficient and thus I defer to a GLS estimation method. Litzenberger and Ramaswamy (1979) (later LR) suggest a two-stage GLS method to circumvent the problem of non-stationary regressor variable(s) with certain assumptions about the regression parameters. Recently DNR (1998) and EHO (2002) use the LR 
methodology to determine a relation between stock return and liquidity for a sample of US firms. Following that approach, I first estimate OLS parameters for the following expanded cross sectional model in equation 3 for each month of the sample period.

4. $\operatorname{Re}$ turn $_{i}=\alpha_{R}+\beta_{1}$ Turnover $_{i}+\beta_{2} \log \left(\right.$ size $_{i}+\beta_{3}$ volatility $_{i}+\varepsilon_{R i}$.

The time series means and variances of each parameter are then computed using a weighted LS method under the assumptions of a non-stationary, but serially uncorrelated distribution of the regression parameters. Specifically, the means are variances are computed as follows.

$$
\begin{gathered}
\hat{\beta}_{k}=\sum_{t=1}^{T} Z_{k t} \hat{\beta}_{k t} \\
\operatorname{Var}\left(\hat{\beta}_{k}\right)=\sum_{t=1}^{T} Z_{k t}^{2} \operatorname{Var}\left(\hat{\beta}_{k t}\right)
\end{gathered}
$$

where, $\hat{\beta}_{k t}=$ estimated $k t h$ regression parameter for month $t$, and

$$
Z_{k t}=\frac{\left[\operatorname{Var}\left(\hat{\beta}_{k t}\right)\right]^{-1}}{\sum_{t=1}^{T}\left[\operatorname{Var}\left(\hat{\beta}_{k t}\right)\right]^{-1}} .
$$

Equation 4 above is styled after EHO (2002) in which they add several variables to the basic Fama-French multifactor model to explain variations in cross sectional returns. For the ith exchange at time $t$, the dependent variable is return computed as difference of $\log \left(\right.$ index $_{\mathrm{t}}-$-index $\left._{\mathrm{t}-1}\right)$; the independent variables are $\log ($ market capitalization), turnover ratio, volatility. Log (market capitalization) captures the size effect, turnover ratio measures liquidity, and volatility is computed as the prior 12 months standard deviation. Due to the unavailability of risk free rates for each market (country) 
and book value of equity for the exchange portfolio, I am not able to estimate beta ${ }^{12}$ and book to market ratio. Further the evidence in EHO (2002) and others suggest mixed evidence in regard to the explanatory power of beta and book to market in explaining cross sectional return in a multi factor model.

\section{C.3. Descriptive statistics on index return}

Table 5A and 5B provide descriptive statistics on index return for each exchange and for each of the four regions of the global market. The means of individual exchanges indicate that during the sample period most indices had a risk adjusted return of zero or less. However, there are still significant variations among the exchanges in terms of both absolute and risk adjusted returns. The European indexes mostly did well in terms of mean return while most Asian indexes did poorly in terms of mean return. Figure 1 shows the mean volatility relation for return on the indexes. Clearly, there are high volatility and low volatility indexes; however, no definite relationship between return (mean) and risk (volatility) emerges. So it is perhaps true that cross sectional variation in return can hardly be explained by stand-alone risk only.

From Table 5B, it appears that unlike those of market capitalization, dollar trading volume, and turnover ratio, the means and standard deviations of returns for the regions do not show any consistent pattern. The mean returns places Europe as the leader followed by N. America and S. America, all of which show positive mean returns over

\footnotetext{
${ }^{12}$ I have considered alternative ways to compute beta. One possibility is from the covariance of returns between a computed global market index and the individual exchange index i.e., regression with global market and individual market return instead of their risk premia. However, a stationary beta measure for each exchange over a pre-sample or in-sample period appears to be much less appealing than the moving standard deviation used in the model. The sample time period of 6/7 years is too long to make sense of a stationary beta.
} 
the sample period. Asia/Pacific shows a negative return during the same period. In terms of volatility, S. America shows the highest volatility followed by Asia/Pacific, Europe, and N. America. By looking at the risk adjusted return it is clear that Europe led the pack with 0.16 followed by N. America, 0.11, S. America, 0.06, and Asia/Pacific -0.023 . The dismal performance of Asia/Pacific region during the sample period is due to the Asian market crash that occurred in 1997.

\section{C.4. Regression Results}

Table 6A and 6B reports regression results from several OLS (pooled time series cross sectional) and GLS models for index return using the complete sample and leaving out the month of January from the sample respectively. Note that in all the models (Models 1-4; Model 3 is the complete model mentioned in equation 4), the estimated OLS coefficients for turnover are all significant and positive (around 7\%). This suggests a direct relation between turnover and index return i.e., everything else remaining constant, investors earn a higher rate of return (on average seven percent higher) from high turnover markets than from low turnover markets. The findings regarding the relation between return and turnover are also in marked contrast with results reported in DNR (1998) and EHO (2002) on individual securities, where they find liquidity to be priced factors in return, but provide mixed evidence for pricing of size, beta, and book to market ratio. Both size and volatility fail to be a significant determinant of return in any (Models 2, 3 and 4) of the models. The fact that a zero null hypothesis for the coefficient of volatility cannot be rejected in this data is in contrast with a hypothesized and 
documented inverse relation between return and variance reported in Abel (1988), Backus and Gregory (1993), and Gennotte and Marsh (1993).

The estimated GLS coefficients and the corresponding t-statistics are markedly different from those from the OLS estimates in all Models 1-4. The estimates confirm the bias and inefficiency in the OLS estimates and justify the use of GLS estimates. The coefficient of turnover is significant and positive in all the models. However compared to the OLS point estimates, similar GLS estimates are around $18 \%$. Thus instead of a seven percent increase in return due to one percent increase in turnover as shown by the OLS estimates, GLS estimates point out at an $18 \%$ increase in expected return due to one percent increase in turnover. Size and volatility remain insignificant in all the models and thus do not contribute to explaining the variation in return. Also, for both OLS and GLS equations, the least square line going through the origin cannot be rejected except in Model 1-LR, in which a zero intercept is rejected at greater than $95 \%$ level of confidence. This suggests the limitations of a univariate model, where all unexplained variations are deposited into the intercept term, and indicates the superiority of a multivariate model to explain variations in expected return. The GLS estimates for the coefficient for turnover are positive (between .173 and .189 in Models 1 to 4 with confidence level greater than 99 percent in each instance) and in tune with the direct relation between return and liquidity as predicted by OLS estimates.

I explain the direct relation (significantly positive coefficient) between return and turnover as follows. The explanation goes with understanding the different connotations of turnover, particularly in the context of an individual security and that of a portfolio. Turnover for an individual security implies liquidity, however, for a portfolio, it reflects 
its composition. An illiquid stock, a stock with a low turnover ratio is risky since an investor cannot convert it to cash on demand. A low turnover ratio portfolio on the other hand indicates a high proportion of slow moving, low growth, and seasoned stocks in the portfolio. These portfolios are the conventional low expected return portfolios. On the other hand, high turnover portfolios are the performance portfolios with growth stocks. Rouwenhorst (1999) document a positive relation between return and turnover in emerging markets, and Wermers (2000) reports that high turnover mutual funds beat the Vanguard Index 500 Fund on a net return basis.

I test if any of my results reported in Table 6A are due to the well-known January effect by running all the models (Models 1 to 4) on a sample excluding the month of January. The results are reported in Table 6B. The main results from the tests are as follows. For all OLS and GLS models size fails to be a significant factor, while liquidity and volatility are significant determinants of index return in Models 1-4. The point estimates of coefficients of turnover are approximately the same for the OLS models, but considerably less (from $18 \%$ to $13 \%$ ) for the GLS models. Contrary to the results reported in Table 6A for the entire sample that volatility fails to be significant in any of the OLS models it is significant (at greater than 99\% level of confidence) in GLS Models 3 and 4 and thus indicates a huge turnaround compared to similar estimates in the full sample. Thus the relation between stand-alone risk measured by volatility and index returns are time variant. The overall relation between index return and volatility in the complete sample as shown in Table 6A may be due to a volatility spillover effect from January that resonates over a long time period. 
In order to determine if return is different between emerging and developed markets, I included a dummy variable in Models 1-4. The coefficient for the dummy variable is not significantly different from zero; the other regression coefficients do not change. This implies the intercepts for return are not different for emerging and developed markets. I also run the pooled $\mathrm{OLS}^{13}$ models separately for emerging and developed markets to determine if the turnover return relation (the slope) is different between emerging and developed markets. I report the results in Tables $6 \mathrm{C}$ and $6 \mathrm{D}$. As evident from Tables $6 \mathrm{C}$ and $6 \mathrm{D}$, there are noticeable differences in the regression coefficients. The most striking difference being turnover losing its explanatory power in explaining cross sectional return for developed markets, but remains hugely significant for emerging markets. On the other hand, volatility is the only variable with significant explanatory power to account for cross sectional variation in returns for the developed markets. The actual magnitude of the coefficients for turnover are significantly lower than those in the OLS models for the combined sample (Tables 6A and 6B), while for volatility the coefficients remain somewhat close to similar estimates in the combined sample. This evidence is consistent across the full sample and the sample excluding the month of January.

\section{Conclusion}

I propose and estimate a multivariate regression model for turnover with exchange and country specific factors including size, age, order execution system of the exchanges,

\footnotetext{
${ }^{13}$ I do not run the GLS models, since now 48 exchanges are split between emerging and developed markets and thus there are too few observations in each subgroup to offer confident statistics.
} 
competition for order flow denoted by single vs. multi market system, and growth. The microstructure effect on turnover denoted by order execution system and competition for order flow and their interactions are tied to the legal system of the country. English common law that provides better shareholder protection increases turnover. I use a two stage GLS approach to determine the effect of turnover on index returns. The GLS approach is necessary to circumvent spurious regression results since a univariate analysis of turnover ratio of stock exchanges indicates a non-stationary component. The GLS parameters of the estimated equations indicate that there is a direct relation between index return and turnover ratio. A direct relation between expected return and volatility measured as standard deviation of return is evident only in a sample without the month of January. I interpret the results as supporting return-turnover relation. However, I find evidence of a January effect on the turnover return relation, and also that this relation is exclusively for emerging markets. For developed markets, I find support for a returnvolatility relation. 


\section{Bibliography}

Abel, Andrew, 1988, Stock Prices under Time-varying Dividend Risk: An Exact Solution in an Infinite Horizon General Equilibrium Model, Journal of Monetary Economics, 22, $375-93$

Amihud, Y., and H. Mendelson, 1986, Asset Pricing and Bid Ask spread, Journal of Financial Economics, 17, 223-49

Backus, D., and A. Gregory, 1993, Theoretical Relations between Risk Premiums and Conditional Variance, Journal of Business and Economic Statistics, 11, 177-85

Baker, H. Kent, 1996, Trading Location and Liquidity: An Analysis of U.S. Dealer and Agency Markets for Common Stocks, Financial Markets, Institutions \& Instruments, 5, 4

Beck, T., R. Levine, and N. Loayza, 2000, Finance and the Sources of Growth, Journal of Financial Economics, 58, 261-300

Boutchkova, M. and W. Megginson, 2000, Privatization and the Rise of Global Capital Markets, Financial Management, 29, 31-76

Clayton, M, B. Jorgenson, and K. Kavajecz, 2000, On the Formation and Structure of International Exchanges, Working paper

Coffee Jr., John, 2002, Competition Among Securities Markets: A Path Dependent Perspective, Working paper

Datar, V., N. Naik, and R. Radcliffe, 1998, Liquidity and Stock Returns: An Alternative Test, Journal of Financial Markets, 1, 203-20

Domnowitz, I, Jack Glen, and A. Madhavan, 2001, Liquidity, Volatility, and Equity Trading Costs Across Countries, and Over Time, International Finance, 4, 221-55

Duvofsky, D. and J. Groth, 1984, Exchange Listing and Stock Liquidity, Journal of Financial Research, 7, 291-302

Easley, D., S. Hvidkjaer, and M. O'Hara, 2002, Is Information Risk a Determinant of Asset Returns? Journal of Finance, 57, 2185-2221

Eleswarapu, V. and K. Venkataraman, 2002, The Impact of Legal and Political Institutions on Equity Trading Costs: A Cross-Country Analysis, Working paper

Frost, C., E. Gordon, and A. Hayes, 2002, Stock Exchange Disclosure and Market Liquidity: An Analysis of 50 International Exchanges, Working paper 
Gennoyye, G. and T. Marsh, 1993, Variations in Economic Uncertainty and Risk

Premiums on capital Assets, European Economic Review, 37, 1021-41

Harris, L., 2003, Trading and Exchanges: Market Microstructure for Practitioners, Oxford University Press, NY

Kane, Alex, 1994, Trading Cost Premiums in Capital Asset Returns-A Closed Form Solution, Journal of Banking and Finance, 18, 1177-83

La Porta, R., F. Lopez-de-Silanes, A. Shleifer, and R. Vishny, 1997, Legal Determinants of External Finance, Journal of Finance, 52, 1131-50

La Porta, R., F. Lopez-de-Silanes, A. Shleifer, and R. Vishny, 1998, Law and Finance, Journal of Political Economy, 106, 1113-55

La Porta, R., F. Lopez-de-Silanes, A. Shleifer, and R. Vishny, 2002, Investor Protection and Corporate Valuation, Journal of Finance, 57, 1147-70

Litzenberger, R. and K. Ramaswamy, 1979, The Effect of Personal Taxes and Dividends on Capital Asset Prices: Theory and Empirical Evidence, Journal of Financial Economics, 163-96

Minier, Jenny, 2000, Opening a Stock Exchange, Working paper

Rouwenhorst, K. Geert, 1999, Local Return Factors and Turnover in Emerging Stock Markets, Journal of Finance, 54, 1439-1464

Wermers, Russ, 2000, Mutual fund Performance: an Empirical Decomposition into Stock Picking talent, Style, Transactions Costs, and Expenses, Journal of Finance, 55, 1655-95 


\section{Appendix A}

Define

$s_{i t}=$ Value of shares of the $i t h$ firm traded during the month $t$

$m_{i t}=$ Market capitalization of the ith firm at the end of month $t$

$t_{i t}=\frac{s_{i t}}{m_{i, t-1}}=$ Turnover (ratio) of the $i t h$ firm for month $t$

Consider a portfolio of $\mathrm{n}$ firms. Its turnover is the weighted average of the component $n$ firms turnover and is computed as

$t o_{p t}=\sum_{i=1}^{n} p_{i} t o_{i t}$

where $p_{i}$ is a firm specific weight.

$t o_{p t}=\sum_{i=1}^{n} p_{i} \frac{s_{i t}}{m_{i, t-1}}$

Let us define $p_{i}=\frac{m_{i, t-1}}{\sum_{i=1}^{n} m_{i, t-1}}$.

Therefore, $t o_{p t}=\sum_{i=1}^{n} \frac{m_{i, t-1}}{\sum_{i=1}^{n} m_{i, t-1}} \frac{s_{i t}}{m_{i, t-1}}=\frac{1}{\sum_{i=1}^{n} m_{i, t-1}} \sum_{i=1}^{n} s_{i t} \ldots \ldots$. (2)

Now, compute portfolio turnover as below: 
$t o_{p t}=\frac{\sum_{i=1}^{n} s_{i t}}{\sum_{i=1}^{n} m_{i, t-1}}=\frac{1}{\sum_{i=1}^{n} m_{i, t-1}}\left(\sum_{i=1}^{n} s_{i t}\right) \ldots . .(3)$. Note this is equivalent to equation (2) above and implies that value weighted portfolio turnover is equivalent to equally weighted value of shares traded, when the weight is the inverse of market capitalization of the portfolio.

Clearly, for a given portfolio of size $n$, at any month $t, \frac{1}{\sum_{i=1}^{n} m_{i, t-1}}$ is constant. 
Table 1: The top panel reports descriptive statistics on market capitalization and value of shares traded for the individual exchanges; the bottom panel for all exchanges within a region. The mean and standard deviation for each exchange is computed for all available monthly observations from January 1995 to December 2001.

\begin{tabular}{|c|c|c|c|c|c|c|}
\hline Exchange (year opened) & Region & Obs. & Mean $(\$ M)$ & St. deviation & Mean $(\$ M)$ & St. deviation \\
\hline & & & Market & Capitalization & Value of & Equity traded \\
\hline Amex (1911) & N. America & 84 & 117206.23 & 25813.49 & 34872.99 & 29564.44 \\
\hline Amsterdam (1602) & Europe & 72 & 472338.41 & 145711.84 & 29875.87 & 16215.97 \\
\hline Athens (1876) & Europe & 72 & 80399.46 & 53661.05 & 5607.93 & 6108.45 \\
\hline Australia (1987) & Asia/Pacific & 84 & 351150.74 & 108521.79 & 15554.20 & 4646.97 \\
\hline Barcelona (1915) & Europe & 84 & 281109.82 & 117919.77 & 2408.73 & 1559.02 \\
\hline Bilbao (1890) & Europe & 84 & 284619.56 & 102471.97 & 14202.14 & 8345.17 \\
\hline Brussels (1904) & Europe & 72 & 147088.63 & 42542.79 & 3357.74 & 1574.39 \\
\hline Buenos Aires (1854) & S. America & 84 & 46138.71 & 9432.61 & 1866.57 & 1065.14 \\
\hline Copenhagen (1681) & Europe & 84 & 86139.48 & 21144.92 & 4962.11 & 2251.76 \\
\hline Germany (1585) & Europe & 84 & 943000.54 & 301526.11 & 108203.83 & 48567.64 \\
\hline Helsinki (1912) & Europe & 84 & 142025.68 & 99626.14 & 7599.27 & 6454.11 \\
\hline Hong Kong (1980) & Asia/Pacific & 84 & 438343.22 & 123048.26 & 21068.82 & 12755.57 \\
\hline Irish (1793) & Europe & 60 & 64015.11 & 12554.41 & 2301.44 & 1399.26 \\
\hline Istanbul (1985) & Europe & 84 & 43661.72 & 25410.88 & 6547.39 & 4696.49 \\
\hline Italy (1904) & Europe & 84 & 444199.96 & 202772.84 & 37601.05 & 29546.49 \\
\hline Jakarta (1977) & Asia/Pacific & 84 & 47735.57 & 25917.43 & 1723.50 & 1174.64 \\
\hline Johannesburg (1887) & Africa & 84 & 227642.78 & 37645.02 & 4367.16 & 1989.24 \\
\hline Korea (1956) & Asia/Pacific & 84 & 163464.42 & 60369.71 & 27965.18 & 21754.68 \\
\hline Kuala Lumpur (1973) & Asia/Pacific & 84 & 167009.71 & 76195.28 & 6383.84 & 5732.45 \\
\hline Lima (1971) & S. America & 60 & 12008.67 & 2392.14 & 225.19 & 140.52 \\
\hline Lisbon (1901) & Europe & 60 & 52993.66 & 12891.01 & 3186.01 & 1440.01 \\
\hline London (1802) & Europe & 84 & 2039303.26 & 511569.78 & 237352.81 & 116055.78 \\
\hline
\end{tabular}




\begin{tabular}{|c|c|c|c|c|c|c|}
\hline Exchange (year) & Region & Obs. & Market & Capitalization & Value of & Equity traded \\
\hline Luxembourg (1928) & Europe & 84 & 31894.47 & 4684.12 & 91.46 & 62.99 \\
\hline Madrid (1831) & Europe & 84 & 333706.67 & 113745.68 & 30623.42 & 31998.73 \\
\hline Mexico (1894) & N. America & 84 & 120352.10 & 22541.02 & 3754.50 & 2990.41 \\
\hline Montreal (1874) & N. America & 60 & 426641.58 & 115654.81 & 2933.50 & 766.31 \\
\hline NASDAQ (1971) & N. America & 84 & 2466951.33 & 1368758.10 & 677388.09 & 506548.71 \\
\hline New Zealand (1915) & Asia/Pacific & 84 & 27329.06 & 65615.08 & 950.03 & 336.23 \\
\hline NYSE (1792) & N. America & 84 & 8897030.33 & 2397249.23 & 604008.27 & 249313.55 \\
\hline Osaka (1878) & Asia/Pacific & 84 & 2506701.15 & 424365.89 & 18980.69 & 16601.39 \\
\hline Oslo (1819) & Europe & 84 & 56805.02 & 9755.30 & 4073.19 & 1631.62 \\
\hline Paris (1700) & Europe & 72 & 853655.70 & 358973.75 & 46285.49 & 25639.79 \\
\hline Philippine (1927) & Asia/Pacific & 72 & 44019.93 & 20904.89 & 1213.95 & 813.22 \\
\hline Rio de Janeiro (1845) & S. America & 60 & 194914.76 & 53442.89 & 1563.35 & 2680.20 \\
\hline Santiago (1893) & S. America & 84 & 66119.89 & 9242.07 & 579.47 & 343.95 \\
\hline Sao Paulo (1890) & S. America & 84 & 200933.79 & 45998.58 & 8889.26 & 4235.35 \\
\hline Singapore (1973) & Asia/Pacific & 84 & 133977.94 & 27005.37 & 6268.46 & 2618.77 \\
\hline Stockholm (1863) & Europe & 84 & 266129.34 & 80592.23 & 21676.63 & 11923.72 \\
\hline Swiss (1876) & Europe & 84 & 553721.56 & 137136.33 & 45378.12 & 12121.59 \\
\hline Taiwan (1961) & Asia/Pacific & 84 & 276389.19 & 68506.19 & 65673.98 & 35996.80 \\
\hline Tehran (1968) & Asia/Pacific & 84 & 17128.23 & 6573.98 & 207.03 & 167.03 \\
\hline Tel Aviv (1953) & Europe & 84 & 48322.26 & 13101.00 & 1329.23 & 687.02 \\
\hline Thailand (1975) & Asia/Pacific & 84 & 67039.48 & 44497.96 & 3003.68 & 1922.59 \\
\hline Tokyo (1878) & Asia/Pacific & 84 & 3099154.15 & 631508.07 & 108640.20 & 55029.39 \\
\hline Toronto (1874) & N. America & 84 & 571738.30 & 162221.20 & 29325.98 & 13214.73 \\
\hline Vancouver (1907) & N. America & 58 & 6506.50 & 2048.03 & 424.04 & 243.85 \\
\hline Vienna (1771) & Europe & 84 & 32152.69 & 5028.38 & 988.49 & 345.94 \\
\hline Warsaw (1991) & Europe & 84 & 16940.21 & 9682.56 & 780.74 & 597.82 \\
\hline
\end{tabular}




\begin{tabular}{|l|l|l|l|l|l|l|}
\hline Regions of the World & $\begin{array}{l}\text { In-sample } \\
\text { exchanges }\end{array}$ & $\begin{array}{l}\text { Nos. of } \\
\text { Obs. }\end{array}$ & $\begin{array}{l}\text { Mean- Mkt. } \\
\text { Value }\end{array}$ & $\begin{array}{l}\text { St. Dev- } \\
\text { Mkt. Value }\end{array}$ & $\begin{array}{l}\text { Mean- Trd. } \\
\text { Vol. }\end{array}$ & $\begin{array}{l}\text { St. Dev- } \\
\text { Trd. Vol. }\end{array}$ \\
\hline Asia-Pacific & 13 & 984 & 616798.74 & 1024620.79 & 23494.40 & 37809.33 \\
\hline Europe-Africa & 23 & 1891 & 320515.08 & 475384 & 26742.20 & 59054.64 \\
\hline North America & 7 & 531 & 1963595.47 & 3299525.25 & 213152.52 & 367865.33 \\
\hline South America & 5 & 366 & 103907.10 & 82973.01 & 2835.56 & 4059.30 \\
\hline
\end{tabular}

Table 2: The top panel contains descriptive statistics on turnover ratio computed as value of shares traded during a month over the market capitalization at the beginning of the month for individual exchanges; the bottom panel for the regions. The statistics are for available observations for each exchange during the period January 1995 to December 2001.

\begin{tabular}{|l|l|l|l|l|l|}
\hline Exchange & System & Mean & St. deviation & High & Low \\
\hline Amex & Order & 0.364 & 0.357 & 1.360 & 0.035 \\
\hline Amsterdam & Quote & 0.060 & 0.017 & 0.106 & 0.033 \\
\hline Athens & Quote & 0.063 & 0.039 & 0.222 & 0.019 \\
\hline Australia & Quote & 0.046 & 0.012 & 0.075 & 0.027 \\
\hline Barcelona & Order & 0.008 & 0.003 & 0.017 & 0.002 \\
\hline Bilbao & Order & 0.049 & 0.021 & 0.121 & 0.014 \\
\hline Brussels & Quote & 0.022 & 0.006 & 0.048 & 0.014 \\
\hline Buenos Aires & Order & 0.043 & 0.027 & 0.126 & 0.010 \\
\hline Copenhagen & Order & 0.057 & 0.016 & 0.104 & 0.032 \\
\hline Germany & Order & 0.114 & 0.025 & 0.209 & 0.070 \\
\hline Helsinki & Quote & 0.050 & 0.018 & 0.118 & 0.027 \\
\hline Hong Kong & Quote & 0.047 & 0.020 & 0.129 & 0.018 \\
\hline Irish & Quote & 0.038 & 0.024 & 0.164 & 0.012 \\
\hline Istanbul & Quote & 0.132 & 0.052 & 0.287 & 0.045 \\
\hline Italy & Quote & 0.075 & 0.035 & 0.206 & 0.023 \\
\hline
\end{tabular}




\begin{tabular}{|c|c|c|c|c|c|}
\hline Exchange & System & Mean & St. deviation & High & Low \\
\hline Jakarta & Quote & 0.036 & 0.015 & 0.087 & 0.015 \\
\hline Johannesburg & Quote & 0.020 & 0.010 & 0.039 & 0.005 \\
\hline Korea & Quote & 0.169 & 0.099 & 0.467 & 0.056 \\
\hline Kuala Lumpur & Quote & 0.034 & 0.021 & 0.089 & 0.008 \\
\hline Lima & Quote & 0.018 & 0.011 & 0.067 & 0.004 \\
\hline Lisbon & Quote & 0.060 & 0.200 & 0.110 & 0.027 \\
\hline London & Quote & 0.112 & .035 & 0.183 & 0.060 \\
\hline Luxembourg & Quote & .003 & .002 & 0.012 & 0.001 \\
\hline Madrid & Quote & 0.078 & 0.065 & 0.260 & 0.018 \\
\hline Mexico & Quote & 0.031 & 0.020 & 0.189 & 0.015 \\
\hline Montreal & Quote & 0.007 & 0.002 & 0.013 & 0.001 \\
\hline NASDAQ & Quote & 0.256 & 0.060 & 0.444 & 0.159 \\
\hline NYSE & Order & 0.066 & 0.013 & 0.115 & 0.046 \\
\hline New Zealand & Quote & 0.037 & 0.015 & 0.089 & 0.016 \\
\hline Osaka & Quote & 0.008 & 0.007 & 0.034 & 0.001 \\
\hline Oslo & Quote & 0.072 & 0.024 & 0.154 & 0.041 \\
\hline Paris & Quote & 0.053 & 0.012 & 0.076 & 0.025 \\
\hline Philippine & Quote & 0.026 & 0.013 & 0.066 & 0.006 \\
\hline Rio de Janeiro & Quote & 0.008 & 0.012 & 0.093 & 0.002 \\
\hline Santiago & Order & 0.009 & 0.005 & 0.036 & 0.003 \\
\hline Sao Paulo & Order & 0.044 & 0.014 & 0.083 & 0.016 \\
\hline Singapore & Order & 0.048 & 0.020 & 0.140 & 0.019 \\
\hline Stockholm & Quote & 0.079 & 0.030 & 0.177 & 0.036 \\
\hline Swiss & Quote & 0.084 & 0.017 & 0.138 & 0.051 \\
\hline Taiwan & Quote & 0.231 & 0.096 & 0.539 & 0.064 \\
\hline Tehran & Quote & 0.012 & 0.008 & 0.034 & 0.003 \\
\hline
\end{tabular}




\begin{tabular}{|l|l|l|l|l|l|}
\hline Exchange & System & Mean & St. deviation & High & Low \\
\hline Tel Aviv & Order & 0.027 & 0.009 & 0.059 & 0.013 \\
\hline Thailand & Quote & 0.052 & 0.031 & 0.180 & 0.018 \\
\hline Tokyo & Order & 0.035 & 0.013 & 0.072 & 0.015 \\
\hline Toronto & Quote & 0.050 & 0.010 & 0.082 & 0.032 \\
\hline Vancouver & Order & 0.064 & 0.028 & 0.157 & 0.019 \\
\hline Vienna & Quote & 0.030 & 0.009 & 0.055 & 0.013 \\
\hline Warsaw & Quote & 0.053 & 0.026 & 0.181 & 0.021 \\
\hline
\end{tabular}

\begin{tabular}{|l|l|l|l|l|l|}
\hline Regions & Order-Quote & Mean & Std. Deviation & Maximum & Minimum \\
\hline Asia-Pacific & $2-11$ & 0.064 & 0.077 & 0.539 & 0.0013 \\
\hline Europe-Africa & $5-18$ & 0.056 & 0.043 & 0.287 & 0.0009 \\
\hline North America & $3-4$ & 0.128 & 0.192 & 1.359 & 0.0005 \\
\hline South America & $3-2$ & 0.025 & 0.023 & 0.126 & 0.0015 \\
\hline
\end{tabular}


Table 3A: OLS Regression (pooled) results for Turnover; Sample period 1996-2001; Coefficients (t-statistics) are in respective cells; Number of observations 3299.

\begin{tabular}{|c|c|c|c|c|c|}
\hline & Model 1 & Model 2 & Model 3 & Model 4 & Model 5 \\
\hline Intercept & $-1.653(-1.12)$ & $-7.469(-4.85)$ & $6.421(6.21)$ & $-1.586(-1.08)$ & $-7.714(-5.04)$ \\
\hline Time trend & $0.060(7.60)$ & $0.060(7.66)$ & $0.074(9.34)$ & $0.064(8.03)$ & $0.063(8.10)$ \\
\hline Log (market value) & $0.974(7.88)$ & & & $0.940(7.63)$ & \\
\hline Log (age) & $-1.330(-6.81)$ & $-0.727(-3.94)$ & $-0.868(-4.64)$ & $-1.309(-6.73)$ & $-0.722(-3.93)$ \\
\hline Type dummy & $-0.942(-2.44)$ & $-0.389(-1.02)$ & $-0.711(-1.84)$ & $-0.965(-2.51)$ & $-0.423(-1.12)$ \\
\hline Multi market dummy & $0.885(2.33)$ & $-0.055(-0.14)$ & $2.204(6.42)$ & $0.937(2.48)$ & $-0.050(-0.13)$ \\
\hline Log (\# of firms) & & $2.465(12.23)$ & & & $2.466(12.30)$ \\
\hline Growth & & & $10.550(6.06)$ & $9.911(5.74)$ & $10.568(6.21)$ \\
\hline F-stat & 42.01 & 60.26 & 36.71 & 40.83 & 57.21 \\
\hline Adj. R-square & 0.059 & 0.082 & 0.051 & 0.068 & 0.093 \\
\hline
\end{tabular}

t-statistics above (below) $1.96(-1.96)$ and 1.65 (-1.65) signify greater than $95 \%$ and $90 \%$ level of confidence respectively. 
Table 3B: Two-way fixed effect Panel Regression results for Turnover; Sample period 1996 - 2001; Coefficients (t-statistics) are in respective cells; Number of observations 3299.

\begin{tabular}{|l|l|l|l|l|}
\hline & Model 1 & Model 2 & Model 3 & Model 4 \\
\hline Intercept & $16.321(4.54)$ & $14.987(4.25)$ & $17.896(5.04)$ & $13.864(3.97)$ \\
\hline Log (market value) & $-0.998(-2.86)$ & & $-1.230(-3.55)$ & \\
\hline Growth & & & $11.854(8.93)$ & $11.448(8.64)$ \\
\hline Log (number of firms) & & $-1.638(-2.51)$ & & $-1.546(-2.40)$ \\
\hline F-test for no fixed effect & 42.48 & 39.83 & 43.66 & 40.73 \\
\hline R-square & 0.622 & 0.622 & 0.631 & 0.631 \\
\hline
\end{tabular}

t-statistics above (below) 1.96 (-1.96) signifies significance at greater than 95 level of confidence.

Table 3C: One-way (exchange specific) fixed effect Panel Regression results for Turnover; Sample period 1996 - 2001; Coefficients (t-statistics) are in respective cells; Number of observations 3299.

\begin{tabular}{|l|l|l|l|l|}
\hline & Model 1 & Model 2 & Model 3 & Model 4 \\
\hline Intercept & $5.688(1.76)$ & $11.338(3.37)$ & $8.515(2.66)$ & $10.942(3.30)$ \\
\hline Log (market value) & $-0.059(-0.18)$ & & $-0.385(-1.20)$ & \\
\hline Growth & & & $10.834(9.60)$ & $10.688(9.52)$ \\
\hline Log (number of firms) & & $-1.227(-1.89)$ & & $-1.217(-1.90)$ \\
\hline Regime dummy & $1.489(9.46)$ & $1.557(9.81)$ & $1.678(10.72)$ & $1.710(10.86)$ \\
\hline F-test for no fixed effect & 100.43 & 94.06 & 103.43 & 96.52 \\
\hline R-square & & & 0.619 & 0.618 \\
\hline
\end{tabular}

t-statistics above (below) $1.96(-1.96)$ and 1.65 (-1.65) signify greater than $95 \%$ and $90 \%$ level of confidence respectively. 
Table 4: Trend component and test of seasonality for turnover ratio computed as value of shares traded during a month over the market capitalization at the beginning of the month. The statistics are for available observations for the period February 1995 to December 2001.

\begin{tabular}{|c|c|c|c|c|c|}
\hline Exchange & $\begin{array}{l}\text { Trend } \\
\text { component }\end{array}$ & t-stat & $\begin{array}{l}\text { Tau: zero- } \\
\text { mean }\end{array}$ & $\begin{array}{l}\text { Tau: constant } \\
\text { mean }\end{array}$ & $\begin{array}{l}\text { Chi-square test for White } \\
\text { Noise (lag 6) residuals }\end{array}$ \\
\hline Amex & 0.0134 & 19.14* & 0.93 & 0.87 & $119.18^{*}$ \\
\hline Amsterdam & 0.0007 & $11.27^{*}$ & $-2.81^{*}$ & $-2.78^{*}$ & $10.14 *$ \\
\hline Athens & 0.0001 & 0.37 & $-4.95^{*}$ & $-4.92 *$ & $90.13^{*}$ \\
\hline Australia & 0.0001 & 1.79 & $-5.64 *$ & $-5.57^{*}$ & $136.48^{*}$ \\
\hline Barcelona & 0.0001 & $5.183^{*}$ & $-4.82 *$ & $-4.80^{*}$ & $15.42^{*}$ \\
\hline Bilbao & 0.0003 & $2.93 *$ & $-4.01 *$ & $-4.00^{*}$ & $34.34 *$ \\
\hline Buenos Aires & -0.0010 & $-17.60 *$ & $-7.10^{*}$ & $-6.98^{*}$ & $22.00 *$ \\
\hline Brussels & 0.0001 & $3.66^{*}$ & $-3.22^{*}$ & $-3.18^{*}$ & $20.15^{*}$ \\
\hline Copenhagen & 0.0003 & $4.88^{*}$ & $-3.80^{*}$ & $-3.27^{*}$ & $45.69^{*}$ \\
\hline Germany & 0.0001 & 0.80 & $-3.59 *$ & $-3.60^{*}$ & $16.40^{*}$ \\
\hline Helsinki & 0.0005 & $8.87^{*}$ & $-3.07^{*}$ & $-3.04 *$ & $27.31^{*}$ \\
\hline Hong Kong & 0.0000 & 0.38 & $-5.99 *$ & $-5.82 *$ & $91.79^{*}$ \\
\hline Irish & -0.0004 & $-2.48^{*}$ & $-3.76^{*}$ & $-3.68^{*}$ & $26.22 *$ \\
\hline Istanbul & 0.0002 & 0.90 & $-3.91^{*}$ & $-3.83^{*}$ & $10.69^{*}$ \\
\hline Italy & 0.0010 & $8.24 *$ & $-2.07^{*}$ & $-2.03 *$ & $24.94^{*}$ \\
\hline Jakarta & 0.0000 & 0.38 & $-5.30^{*}$ & $-5.29 *$ & $30.44^{*}$ \\
\hline Johannesburg & 0.0004 & $19.69^{*}$ & $-4.53 *$ & $-4.50^{*}$ & $67.28 *$ \\
\hline Korea & 0.0022 & $5.78^{*}$ & $-4.02 *$ & $-3.99^{*}$ & $94.85^{*}$ \\
\hline Kuala Lumpur & -0.0004 & $-4.37^{*}$ & $-5.33^{*}$ & $-5.28^{*}$ & $12.78^{*}$ \\
\hline Lima & -0.0002 & $-3.34 *$ & $-2.83^{*}$ & $-2.81^{*}$ & 2.88 \\
\hline Lisbon & -0.0003 & -1.70 & -1.86 & -1.95 & $11.18^{*}$ \\
\hline London & 0.0012 & $13.08^{*}$ & $-2.50^{*}$ & $-2.43^{*}$ & 8.21 \\
\hline Luxembourg & 0.0001 & $2.47 *$ & $-3.67^{*}$ & $-3.66^{*}$ & $29.14 *$ \\
\hline
\end{tabular}




\begin{tabular}{|c|c|c|c|c|c|}
\hline Exchange & $\begin{array}{l}\text { Trend } \\
\text { component }\end{array}$ & t-stat & $\begin{array}{l}\text { Tau: zero- } \\
\text { mean }\end{array}$ & $\begin{array}{l}\text { Tau: constant } \\
\text { mean }\end{array}$ & $\begin{array}{l}\text { Chi-square test for White } \\
\text { Noise (lag 6) residuals }\end{array}$ \\
\hline Madrid & 0.0020 & $10.33 *$ & $-4.29 *$ & $-4.23 *$ & $115.94 *$ \\
\hline Mexico & 0.0000 & 0.26 & $-3.75^{*}$ & $-3.81^{*}$ & 1.36 \\
\hline Montreal & -0.0001 & $-7.78^{*}$ & $-3.05^{*}$ & $-3.11^{*}$ & $17.91 *$ \\
\hline NASDAQ & 0.0017 & $8.20^{*}$ & $-2.39 *$ & $-2.37^{*}$ & $12.84 *$ \\
\hline NYSE & 0.0004 & $10.54 *$ & -1.69 & -1.65 & $19.06^{*}$ \\
\hline New Zealand & 0.0004 & $6.28^{*}$ & $-3.34 *$ & $-3.30 *$ & $17.26^{*}$ \\
\hline Osaka & -0.0000 & -0.67 & $-2.49 *$ & $-2.47^{*}$ & $7.03 *$ \\
\hline Oslo & 0.0005 & $5.37^{*}$ & $-5.19 *$ & $-5.14 *$ & $11.70^{*}$ \\
\hline Paris & 0.0004 & $7.94 *$ & $-2.78^{*}$ & $-2.72^{*}$ & $10.78^{*}$ \\
\hline Philippine & -0.0002 & $-3.18^{*}$ & $-4.38^{*}$ & $-4.35^{*}$ & $48.36^{*}$ \\
\hline Rio de Janeiro & 0.0000 & 0.02 & -0.23 & -0.21 & 1.07 \\
\hline Santiago & -0.0001 & $-2.92 *$ & $-4.49 *$ & $-4.46^{*}$ & $14.42^{*}$ \\
\hline Sao Paulo & -0.0002 & $-3.10^{*}$ & $-5.74 *$ & $-5.59 *$ & $74.60 *$ \\
\hline Singapore & 0.0002 & $2.59^{*}$ & $-5.34 *$ & $-5.32 *$ & $27.94 *$ \\
\hline Stockholm & 0.0010 & $12.70^{*}$ & -1.25 & -1.23 & $23.72 *$ \\
\hline Swiss & -0.0002 & $-2.84^{*}$ & $-6.20^{*}$ & $-6.15^{*}$ & $17.42^{*}$ \\
\hline Taiwan & -0.0001 & -0.21 & $-5.00^{*}$ & $-5.01 *$ & $53.86^{*}$ \\
\hline Tehran & 0.0000 & 1.09 & $-3.78^{*}$ & $-3.76^{*}$ & $26.69^{*}$ \\
\hline Tel Aviv & 0.0001 & $2.43^{*}$ & $-4.62 *$ & $-4.59 *$ & $55.62^{*}$ \\
\hline Thailand & 0.0005 & $3.91 *$ & $-2.60 *$ & $-2.57 *$ & 4.93 \\
\hline Tokyo & 0.0004 & $11.88^{*}$ & $-3.88^{*}$ & $-3.81^{*}$ & $40.82^{*}$ \\
\hline Toronto & 0.0003 & $7.83^{*}$ & $-2.59 *$ & $-2.54 *$ & $17.71^{*}$ \\
\hline Vancouver & -0.0011 & $-6.96^{*}$ & $-5.72 *$ & $-5.60 *$ & $12.87^{*}$ \\
\hline Vienna & -0.0001 & $-3.78^{*}$ & $-5.44 *$ & $-5.36^{*}$ & $33.07 *$ \\
\hline Warsaw & -0.0005 & $-4.18^{*}$ & $-3.28 *$ & $-3.24 *$ & 5.86 \\
\hline
\end{tabular}

Asterisk indicates significance at greater than/equal to $90 \%$ level of confidence 
Table 5A: Descriptive statistics on continuously compounded Index Return for individual exchanges computed as the difference between $\log$ (index) at two consecutive times, $\mathrm{t}$ and $(\mathrm{t}-1)$.

\begin{tabular}{|c|c|c|c|c|c|}
\hline Exchange & Index & Mean & St. deviation & High & Low \\
\hline Amex & Market value & 0.008 & 0.048 & 0.123 & -0.223 \\
\hline Amsterdam & AAX & 0.021 & 0.060 & 0.279 & -0.131 \\
\hline Athens & General price & 0.014 & 0.106 & 0.346 & -0.251 \\
\hline Australia & All ordinary & 0.007 & 0.036 & 0.073 & -0.116 \\
\hline Barcelona & General price & 0.014 & 0.066 & 0.174 & -0.217 \\
\hline Bilbao & Gal index 2000 & 0.016 & 0.065 & 0.151 & -0.222 \\
\hline Brussels & General price & 0.002 & 0.087 & 0.010 & -0.618 \\
\hline Buenos Aires & Merval & -0.001 & 0.097 & 0.341 & -0.366 \\
\hline Copenhagen & KAX all share & 0.008 & 0.045 & 0.010 & -0.120 \\
\hline Germany & DAX price & 0.008 & 0.067 & 0.166 & -0.195 \\
\hline Helsinki & HEX price & 0.019 & 0.100 & 0.258 & -0.313 \\
\hline Hong Kong & All ordinary & 0.004 & 0.089 & 0.222 & -0.344 \\
\hline Irish & ISEQ price & 0.011 & 0.058 & 0.133 & -0.189 \\
\hline Istanbul & ISE Nat 100 & 0.043 & 0.170 & 0.587 & -0.495 \\
\hline Italy & MIB Hist. Price & 0.009 & 0.071 & 0.208 & -0.179 \\
\hline Jakarta & Composite & -0.001 & 0.110 & 0.322 & -0.379 \\
\hline Johannesburg & Actuaries & 0.009 & 0.069 & 0.123 & -0.387 \\
\hline Korea & Composite & -0.004 & 0.116 & 0.411 & -0.318 \\
\hline Kuala Lumpur & Composite & -0.003 & 0.105 & 0.294 & -0.285 \\
\hline Lima & IGBVL & -0.005 & 0.081 & 0.250 & -0.304 \\
\hline Lisbon & PSI General & 0.008 & 0.070 & 0.159 & -0.185 \\
\hline London & FT-SE 100 & 0.007 & 0.039 & 0.085 & -0.112 \\
\hline Luxembourg & Lux Gal price & 0.004 & 0.066 & 0.132 & -0.321 \\
\hline
\end{tabular}




\begin{tabular}{|c|c|c|c|c|c|}
\hline Exchange & Index & Mean & St. deviation & High & Low \\
\hline Madrid & General price & 0.013 & 0.061 & 0.142 & -0.215 \\
\hline Mexico & $P \& Q$ & 0.013 & 0.100 & 0.177 & -0.350 \\
\hline Montreal & XXM & 0.013 & 0.048 & 0.106 & -0.220 \\
\hline NASDAQ & Composite & 0.011 & 0.093 & 0.199 & -0.26 \\
\hline NYSE & Composite & 0.010 & 0.041 & 0.089 & -0.162 \\
\hline New Zealand & Gross & 0.007 & 0.045 & 0.103 & -0.148 \\
\hline Osaka & 300 Composite & -0.003 & 0.050 & 0.112 & -0.140 \\
\hline Oslo & Total price return & 0.007 & 0.058 & 0.115 & -0.256 \\
\hline Paris & SBF 250 & 0.016 & 0.051 & 0.115 & -0.129 \\
\hline Philippine & Composite & -0.013 & 0.100 & 0.332 & -0.299 \\
\hline Rio de Janeiro & IBV & 0.023 & 0.124 & 0.224 & -0.531 \\
\hline Santiago & IGPA & -0.000 & 0.053 & 0.154 & -0.234 \\
\hline Sao Paulo & Bovespa & 0.014 & 0.119 & 0.247 & -0.503 \\
\hline Singapore & All share & -0.002 & 0.077 & 0.232 & -0.233 \\
\hline Stockholm & SE All Share & 0.011 & 0.062 & 0.151 & -0.155 \\
\hline Swiss & SPI Return & 0.012 & 0.051 & 0.115 & -0.199 \\
\hline Taiwan & Weighted & -0.002 & 0.090 & 0.224 & -0.215 \\
\hline Tehran & TEPIX & 0.021 & 0.044 & 0.216 & -0.064 \\
\hline Tel Aviv & General & 0.011 & 0.066 & 0.158 & -0.178 \\
\hline Thailand & SET & -0.017 & 0.117 & 0.284 & -0.281 \\
\hline Tokyo & TOPIX & -0.004 & 0.053 & 0.123 & -0.132 \\
\hline Toronto & Composite & 0.008 & 0.054 & 0.112 & -0.226 \\
\hline Vancouver & Composite & -0.011 & 0.081 & 0.145 & -0.231 \\
\hline Vienna & Wiener Borse Index & 0.002 & 0.047 & 0.101 & -0.177 \\
\hline Warsaw & WIG & 0.053 & 0.100 & 0.350 & -0.351 \\
\hline
\end{tabular}


Figure 1: Risk return diagram for global stock exchanges. The horizontal axis is for exchanges in alphabetical order. The vertical axis represents both monthly return and the corresponding volatility for the stock exchanges. The sample period is 1996-2001.

Risk-Return Diagram

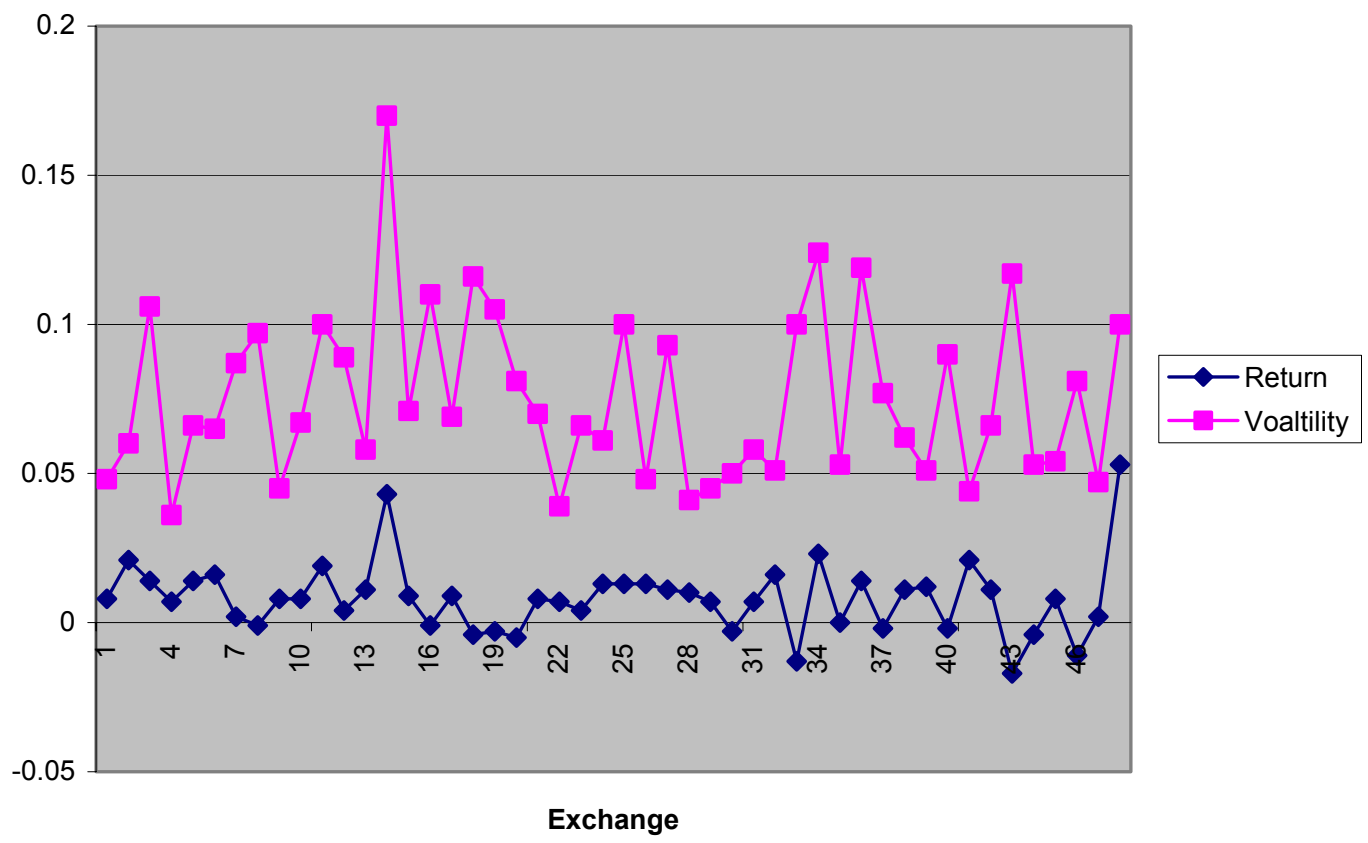

Table 5B: Descriptive statistics on continuously compounded Index Return computed as the difference between $\log$ (index) at two consecutive times, $t$ and ( $t-1)$ for regions of the world.

\begin{tabular}{|l|l|l|l|l|l|}
\hline Regions & Mean & St. deviation & Risk adj. Return & High & Low \\
\hline Asia-Pacific & -0.002 & 0.086 & 0.023 & 0.411 & -0.379 \\
\hline Europe-Africa & 0.012 & 0.075 & 0.160 & 0.587 & -0.618 \\
\hline North America & 0.008 & 0.070 & 0.114 & 0.199 & -0.350 \\
\hline South America & 0.006 & 0.100 & 0.060 & 0.341 & -0.531 \\
\hline
\end{tabular}


Table 6A: Average intercepts and slope coefficients (t-statistics inside parentheses) for regression models for return for all months during the period 1996-2001

\begin{tabular}{|l|l|l|l|l|l|}
\hline & Intercept & Turnover & Log (size) & Volatility & F-stat \\
\hline Model 1-OLS & $0.001(0.81)$ & $0.074(4.95)$ & & & 24.46 \\
\hline Model 1-LR & $-0.007(-1.97)$ & $0.184(2.89)$ & & & \\
\hline Model 2-OLS & $-0.005(-0.45)$ & $0.072(4.79)$ & $0.001(0.58)$ & & 12.40 \\
\hline Model 2-LR & $0.007(0.48)$ & $0.173(2.79)$ & $-0.001(-0.71)$ & & \\
\hline Model 3-OLS & $0.000(0.00)$ & $0.074(4.88)$ & $0.000(0.35)$ & $-0.038(-1.00)$ & 8.60 \\
\hline Model 3-LR & $0.031(1.65)$ & $0.203(3.27)$ & $-0.002(-1.50)$ & $-0.178(-2.87)$ & \\
\hline Model 4-OLS & $0.004(1.37)$ & $0.075(5.03)$ & & $-0.041(-1.10)$ & 12.84 \\
\hline Model 4-LR & $0.003(0.78)$ & $0.191(2.84)$ & & $-0.167(-2.96)$ & \\
\hline
\end{tabular}

Table 6B: Average intercepts and slope coefficients for regression models for return for all months except January during the period 1996-2001; t-statistics are in parentheses.

\begin{tabular}{|l|l|l|l|l|l|}
\hline & Intercept & Turnover & Log (size) & Volatility & F-stat. \\
\hline Model 1-OLS & $-0.000(-0.13)$ & $0.068(4.46)$ & & & 19.91 \\
\hline Model 1-LR & $-0.012(-4.94)$ & $0.132(3.07)$ & & & \\
\hline Model 2-OLS & $-0.015(-1.30)$ & $0.065(4.20)$ & $0.001(1.29)$ & & 10.79 \\
\hline Model 2-LR & $-0.019(-1.55)$ & $0.108(2.44)$ & $0.001(0.95)$ & & \\
\hline Model 3-OLS & $-0.007(-0.55)$ & $0.068(4.37)$ & $0.001(0.93)$ & $-0.061(-1.55)$ & 8.01 \\
\hline Model 3-LR & $0.003(0.25)$ & $0.140(4.63)$ & $0.000(0.25)$ & $-0.263(-4.64)$ & \\
\hline Model 4-OLS & $0.004(1.39)$ & $0.071(4.62)$ & & $-0.069(-1.79)$ & 11.57 \\
\hline Model 4-LR & $0.007(1.77)$ & $0.140(4.90)$ & & $-0.299(-5.73)$ & \\
\hline
\end{tabular}

For Tables 6A and 6B, t-statistics above (below) $1.96(-1.96)$ signifies significance at greater than 95 level of confidence. 
Table 6C: Intercepts and slope coefficients for regression models (pooled OLS) for return for all months during the period 1996-2001 for emerging and developed markets; t-statistics inside parentheses.

\begin{tabular}{|l|l|l|l|l|l|}
\hline & Intercept & Turnover & Log (size) & Volatility & F-stat \\
\hline Model 1-Emer & $-0.014(-3.60)$ & $0.292(7.24)$ & & & 52.40 \\
\hline Model 1-Dev & $0.007(4.05)$ & $0.013(0.95)$ & & & 0.91 \\
\hline Model 2-Emer & $0.008(0.23)$ & $0.298(7.18)$ & $-0.002(-0.61)$ & & 26.37 \\
\hline Model 2-Dev & $0.001(0.09)$ & $0.012(0.87)$ & $0.001(0.60)$ & & 0.63 \\
\hline Model 3-Emer & $0.006(0.15)$ & $0.296(6.83)$ & $-0.002(-0.56)$ & $0.011(0.16)$ & 17.58 \\
\hline Model 3-Dev & $0.016(1.48)$ & $0.017(1.32)$ & $0.000(0.48)$ & $-0.255(-4.62)$ & 7.54 \\
\hline Model 4-Emer & $-0.016(-2.27)$ & $0.289(6.96)$ & & $0.021(0.30)$ & 26.23 \\
\hline Model 4-Dev & $0.021(6.05)$ & $0.018(1.40)$ & & $-0.255(-4.63)$ & 11.20 \\
\hline
\end{tabular}

Table 6D: Intercepts and slope coefficients for regression models (pooled OLS) for return for all months except January for emerging and developed markets during the period 1996-2001; t-statistics are in parentheses.

\begin{tabular}{|l|l|l|l|l|l|}
\hline & Intercept & Turnover & Log (size) & Volatility & F-stat. \\
\hline Model 1-Emer & $-0.015(-3.89)$ & $0.272(6.53)$ & & & 42.67 \\
\hline Model 1-Dev & $0.006(3.16)$ & $0.011(0.80)$ & & & 0.64 \\
\hline Model 2-Emer & $-0.031(-0.84)$ & $0.268(6.25)$ & $0.001(0.43)$ & & 21.41 \\
\hline Model 2-Dev & $-0.002(-0.21)$ & $0.100(0.70)$ & $0.001(0.75)$ & & 0.60 \\
\hline Model 3-Emer & $-0.028(-0.68)$ & $0.271(6.05)$ & $0.001(0.36)$ & $-0.018(-0.25)$ & 14.29 \\
\hline Model 3-Dev & $0.012(1.06)$ & $0.115(1.10)$ & $0.001(0.65)$ & $-0.235(-4.19)$ & 6.25 \\
\hline Model 4-Emer & $-0.013(-1.89)$ & $0.276(6.43)$ & & $-0.024(-0.35)$ & 21.38 \\
\hline Model 4-Dev & $0.018(5.23)$ & $0.016(1.20)$ & & $-0.236(-4.21)$ & 9.17 \\
\hline
\end{tabular}

For Tables 6C and 6D, t-statistics above (below) $1.96(-1.96)$ signifies significance at greater than 95 level of confidence. 